\title{
sciendo
}

\section{EFFECTIVENESS EVALUATION OF USE OF VARIOUS PROTEIN FEEDS FOR BROILER CHICKEN FEEDING*}

\author{
Anna Milczarek`, Maria Osek \\ Department of Animal Nutrition and Feed Management, Siedlce University of Natural Sciences and \\ Humanities, B. Prusa 14, 08-110 Siedlce, Poland \\ •Corresponding author: anna.milczarek@uph.edu.pl
}

\begin{abstract}
The purpose of this paper was to assess the suitability of various protein feeds in broiler chicken feeding. The study covered 160 birds split into 5 equipotent groups (SBM, EFFS, RFFS, EL, DDGS). Four protein feeds were an experimental factor: extruded full-fat soybean (EFFS group), raw full-fat soybean (RFFS group), extruded lupine (EL group) and distillers dried grains with solubles (DDGS group) that were added to starter rations in an amount replacing $30 \%$, and in grower and finisher rations $\mathbf{5 0 \%}$ of extracted soybean meal protein. Results showed that after replacing an identical amount of extracted soybean meal protein with protein from extruded soybean or DDGS in chicken rations, the final body weight and feed conversion ratio were similar to those of birds from the control group. Deterioration $(P \leq 0.01)$ in the above-mentioned parameters was observed for chickens fed with rations containing raw soybean or extruded lupine. Birds that were given rations containing raw soybean (RFFS group) were characterized by the lowest dressing percentage, and, compared to the control group, the difference was significant $(\mathrm{P} \leq \mathbf{0 . 0 1})$. The type of protein feed contained in the rations did not affect the musculature of chickens, however it did impact their fat deposition. Fat deposition was the lowest in birds from RFFS and DDGS groups that reached the lowest final body weight. Microscopic images of all examined livers showed a normal histological structure. The results of the studies carried out provide a basis for recommending the use of extruded full-fat soybean or DDGS in broiler chicken rations as partial substitutes for extracted soybean meal protein.
\end{abstract}

Key words: protein feeds, broiler chickens, slaughter value, liver histological image

High protein content and its amino acids composition as well as small amount of anti-nutritive substances render the extracted soybean meal (SBM) an excellent protein feed in broiler chicken rations. However, due to variations in its price and supply throughout the world and in connection with public concern about genetically modified plants, attempts have been made to substitute SBM with other protein

\footnotetext{
*Work financed from statutory activity, project no. 212/04/S.
} 
feeds (Domingo and Bordonaba, 2011; Olkowski et al., 2016; Erdaw et al., 2018). In Europe (and Poland) area of legume seeds and non-GMO soybeans has been growing (Recknagel, 2015; Statistical Yearbook of Agriculture, 2018). In the past decade, a number of studies were also carried out (Loeffler et al., 2013; Zhaleh et al., 2014; Rutkowski et al., 2016; Tomaszewska et al., 2018) that assessed the suitability of legume seeds in rations for birds. Unfortunately, feeding them with a meal substituting the extracted soybean meal in full is not possible due to the presence of a number of anti-nutritive substances which have been negatively affecting chicken production and health indicators (Moschini et al., 2005; Olkowski et al., 2016). In order to improve the nutritional value of raw seeds, they undergo pressure-thermal treatment (Leontowicz et al., 1999; Moschini et al., 2005; Palliyeguru et al., 2011; Loeffler et al., 2013). The extrusion process reduces the activity of thermolabile harmful substances, decreases the negative action of oligosaccharides and protease inhibitors and increases amino acid digestibility (Loeffler et al., 2013; Jahanian and Rasouli, 2016). The positive effect of the extrusion of soybeans on the production performance of broiler chickens was demonstrated by Palliyeguru et al. (2011), but the authors did not provide information about the variety of soybean (GMO or non-GMO). Rutkowski et al. (2016), however, believe that not only does the pressure-thermal treatment itself affect the results of rearing, but the beans and their inclusion rate have an impact as well. The authors showed that an inclusion of 10 or $20 \%$ of raw or extruded lupine in the rations does not affect the chicken rearing performance, although the extrusion process can improve them. Pressure-thermal treatment is recommended only when 25 or $30 \%$ of lupine is added to the rations. Another protein feed many researchers are interested in (Lumpkins et al., 2004; Wang et al., 2007; Lukaszewicz and Kowalczyk, 2014; Sariozkan et al., 2015; Mir et al., 2018) is DDGS. DDGS is a major coproduct of grain-based ethanol production. It is available in large quantities, and at the same time is an inexpensive, renewable and sustainable resource. The United States and the European Union are the major producers of grain-based ethanol (Chatzifragkou et al., 2015). DDGS show differences in chemical composition (Alaeldein et al., 2017; He et al., 2017). Dzuman et al. (2016) and He et al. (2017) showed that DDGS could contain different amount of sulphur or mycotoxins, which can pose a certain risk for animals. The opinions on using DDGS in rations for broiler chickens are quite varied. Lumpkins et al. (2004) demonstrated that corn DDGS can be used in broiler nutrition at $6 \%$ in the starter ration $2 \%$ in the grower and up to $15 \%$ in the finisher ration, while higher levels of this feed $(18 \%)$ decrease the dynamics of chicken growth and feeding efficiency. Wang et al. (2007) proved that good-quality DDGS can be used in broiler diets at levels amounting to $15-20 \%$, with little adverse effect on live performance but might result in some loss of dressing percentage or breast meat share. Lukaszewicz and Kowalczyk (2014) recommend 5\% of DDGS in the diets of broiler chickens, as only such content does not reduce rearing performance and meat quality. According to Mir et al. (2018) 5 or $10 \%$ of DDGS in rations will not affect the body weight of broiler chickens but it will significantly reduce feed conversion ratio. However, Sariozkan et al. (2015) assume that $30 \%$ of DDGS in the rations will not affect rearing performance. Numerous studies (Corzo et al., 2009; Jiang et al., 2014; Lukaszewicz and Kowalczyk, 2014; Mir et al., 2018) 
showed that the bird's diet not only affects rearing performance but can also modify the physicochemical properties of meat. However, little is known about the effect of rations containing evaluated protein feeds on the quality of broilers' meat.

The purpose of the research carried out was to assess the nutritional suitability of various protein feeds as partial $(30 \%$ in starter, $50 \%$ in grower and finisher rations) substitutes for extracted soybean meal protein in rations fed to broiler chickens.

\section{Material and methods}

The research began with an assessment of the nutritional value of protein feeds (extracted soybean meal, raw and extruded soybean, extruded lupine, and distiller's dried grains) and other components used in the nutritional experiment involving broiler chickens. The content of dry matter, crude protein, crude fat, crude fibre and crude ash according to AOAC (1990) was determined. Moreover, the amount of tannins (BN-90/91160-62) was determined in protein feeds. The method consisted of extracting tannins by means of a mixture of ethyl alcohol, glycerol and water, coloured complex with a phosphotungsten-phosphomolybdene reagent and measuring the rate of absorption of the coloured solution at a wavelength of $700 \mathrm{~nm}$. The antitrypsin activity was determined in the above-mentioned feeds using the method developed by Smith et al. (1980) that applies a spectrophotometric measurement of absorption of casein degradation products by trypsin in the presence of an inhibitor. Amino acids (except tryptophan) were determined by UPLC-UV ultraperformance liquid chromatography with spectrophotometric detection (PB 59 KLP, 2014). Tryptophan was, on the other hand, determined by HPLC-FLD high performance liquid chromatography with fluorescence detection (Commission Regulation, 2009).

The study was carried out using 160 Ross 308 chickens. They were split into 5 equipotent groups (SBM, EFFS, RFFS, EL, DDGS). One-day-old chickens were weighed and randomly placed in 20 metal cages, 2 cocks and 2 cockerels in each, which constituted 8 replicates per feeding group. All cages (dimensions of $0.5 \mathrm{~m} \times$ $1 \mathrm{~m}$ ) were located in the same room under the same environmental conditions, and the chickens had permanent access to feed and water. Electric lighting was applied on a 24-hour basis throughout the rearing period. In the first week of the study, the ambient temperature was $32^{\circ} \mathrm{C}$. Next it was reduced by $1-2^{\circ} \mathrm{C}$ each week ( 7 days) to reach $21-23^{\circ} \mathrm{C}$ in the last week of rearing. The chickens were kept for 42 days that were divided into 3 feeding periods: starter (1-21 days), grower (22-35 days) and finisher (36-42 days). The complete rations were formulated in accordance with the Standards and Recommendations of Poultry Nutrition (2005) so they were iso-energetic and iso-protein. The nutritional value of the rations was calculated based on the chemical composition of feed materials, while the metabolizable energy content was based on the WPSA equations (1989). The rations were produced internally from maize extracted soybean meal (SBM) and mineral and vitamin additives. To balance 
the level of metabolizabe energy soybean oil was used. The soybean oil contained (\% total fatty acids): 14.59 - SFA, 22.50 - MUFA, 58.06 - PUFAn-6 and 4.77 PUFA $n-3$. The experimental factor was protein feeds: non-GMO extruded full-fat soybean (EFFS group), non-GMO raw full-fat soybean (RFFS group), extruded lupine (EL group) and distiller's dried grains (DDGS group). They were introduced into the starter rations replacing $30 \%$ of extracted soybean meal protein and $50 \%$ in the grower and finisher rations. The raw material composition and nutritional value of the rations are specified in Table 1.

During the research, the body weight of chickens on days 1, 21, 35 and 42 of rearing, the amount of loose feed consumed and any possible chicken deaths were monitored. This data was used to calculate body weight gain (BWG), feed intake (FI) and feed conversion ratio (FCR). After 42 days of rearing, 8 birds (4 cocks and 4 cockerels) of a weight similar to the average weight for the group and sex were slaughtered from each group. Further, 15 minutes after slaughter, the $\mathrm{pH}\left(\mathrm{pH}_{1}\right)$ of the breast muscles was measured via $\mathrm{pH}$-meter Testo 205 Set. Then, carcasses were cooled for 24 hours at $4^{\circ} \mathrm{C} \cdot \mathrm{pH}_{24}$ was then again determined and a simplified slaughter analysis was carried out according to Ziołecki and Doruchowski (1989). Breast muscle samples (musculus pectoralis) were collected from each bird for physicochemical and organoleptic determination.

Moreover, during the chickens gutting, the specimens of liver left lobes were taken for morphological evaluation. They were preserved (for $24 \mathrm{~h}$ ) in $10 \%$ formol and absolute alcohol and then increasing concentrations of solutions of alcohol and xylene in the tissue processor, and then drowned in paraffin blocks. Further, $4 \mu \mathrm{m}$ thick histological sections stained with hematoxylin and eosin (HE) were examined. Histochemical staining of liver was also carried out for the presence of neutral fats in which specimens preserved in $10 \%$ neutral formalin were cut and stained with Sudan IV according to the Daddi method (Zawistowski, 1983). The evaluation was performed using a light microscope (Nicon Eclipse E-600) with a digital camera (Nicon DS.-Fi1) and a computer software for image analysis (NIS-Elements BR-2.20, Laboratory Imaging).

The content of basic ingredients in the feed and breast muscle (without crude fibre) was determined according to AOAC (1990). The fatty acid profile of the lipid fraction was determined by gas chromatography of methyl esters using a Varian 450GC gas chromatograph equipped with a flame ionization detector (air-hydrogen). A Select ${ }^{\mathrm{TM}}$ Biodiesel for FAME capillary column was used $(30 \mathrm{~m}, 0.32 \mathrm{~mm}, 0.25$ $\mu \mathrm{m})$ with a Select Biodiesel for FAME Fused Silica filling. Injector temperature was $250^{\circ} \mathrm{C}$, detector $-300^{\circ} \mathrm{C}$ and $200^{\circ} \mathrm{C}$ of the column (initial) and $240^{\circ} \mathrm{C}$ (final). Helium was used as a carrier gas, with a flow of $2.5 \mathrm{ml}$ per minute.

Water holding capacity of muscles was determined according to Grau and Hamm's (1953) method with Pohja and Niinivaara's modifications (1957), based on the amount of free water (expressed in \%) lost by the sample of meat placed on the filter paper and kept under pressure between two glass plates. Infiltration of the surface area $\left(\mathrm{cm}^{2}\right)$ was measured and amount of free water calculated with a planimeter, assuming the associated infiltration $1 \mathrm{~cm}^{2} 10 \mathrm{mg}$ muscle juice absorbed by filter paper. 


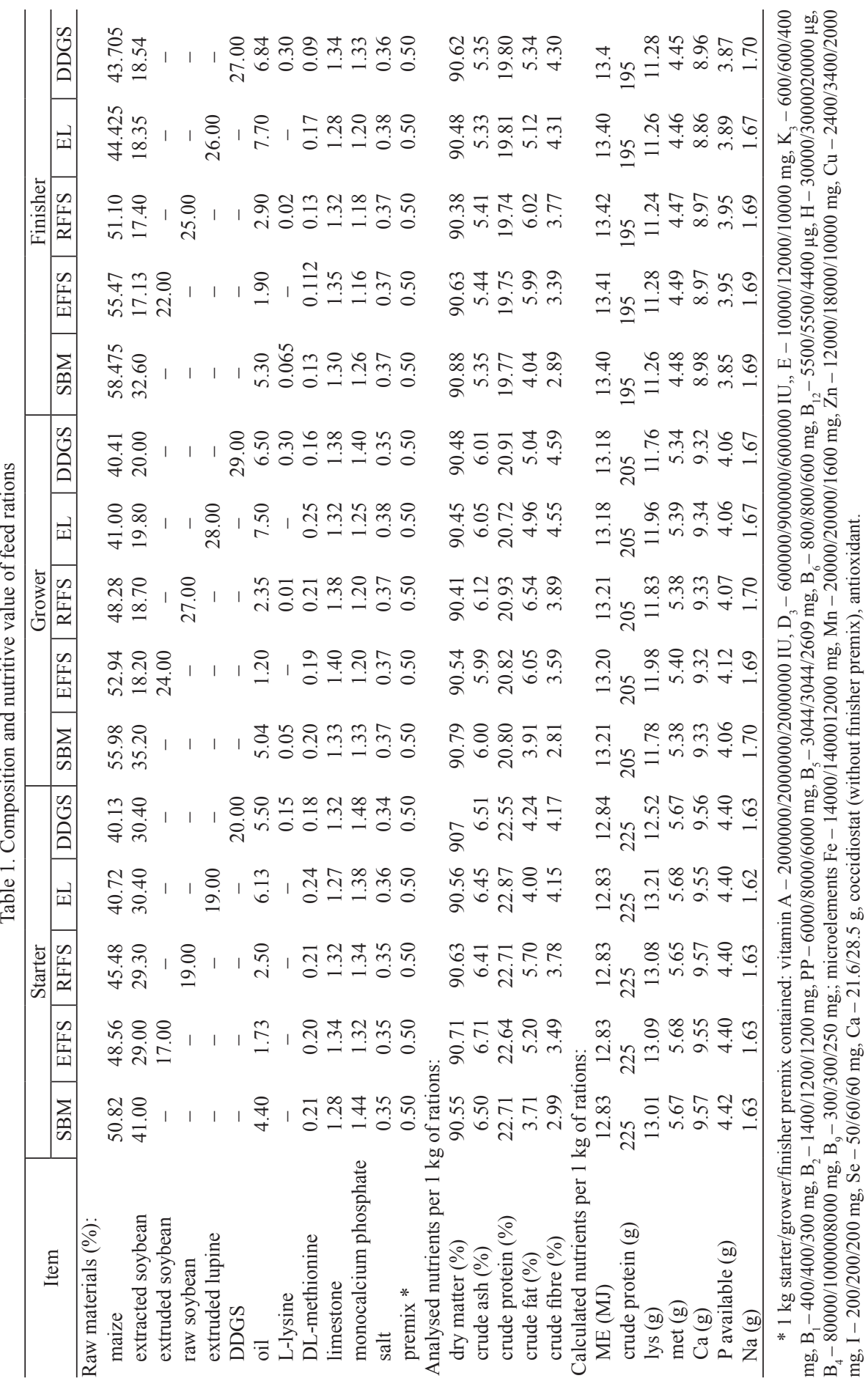


The instrumental colour evaluation was performed by means of a tristimulus colorimeter. The colour description model was $\mathrm{L}^{*} \mathrm{a}^{*} \mathrm{~b}^{*}$. In the measuring system used $\mathrm{L}^{*}$ stands for lightness which is a space vector. On the other hand, $\mathrm{a}^{*}$ and $\mathrm{b}^{*}$ are trichromatic coordinates, where $\mathrm{a}^{*}$ as a positive value corresponds to red, as a negative value to green, positive $b^{*}$ to yellow, and negative $b^{*}$ to blue. Based on the results of the analysis of $\mathrm{a}^{*} \mathrm{~b}^{*}$ colour parameters, the chroma $(\mathrm{C})$ and hue $(\mathrm{H})$ of the colour were calculated from the formulas (Milczarek and Osek, 2016).

The sensory evaluation of the muscle (after thermal treatment) was conducted using a 5-point scale: from 1 (minimum) to 5 (maximum). Muscles were heated in an aqueous solution of $0.8 \% \mathrm{NaCl}$ (assuming the meat to water ratio of 1:2) to reach a temperature of $80^{\circ} \mathrm{C}$ at the geometric center of the sample. The evaluation was performed by a group of 8 trained people. The samples were evaluated for palatability, flavour, juiciness and tenderness (Baryłko-Pikielna and Matuszewska, 2014).

The obtained results were analysed statistically using one-way analysis of variance. Duncan's test was used to determine the significance of differences between mean values of the groups (StatSoft, 2015).

\section{Results}

The chemical composition of the examined protein feeds was presented in Table 2 proving that it was differentiated. It has been demonstrated that extrusion of raw soybeans increased the content of protein, proportionally increasing the level of amino acids in the protein, and reduced the content of crude fibre by approximately $10 \%$. The analysis of selected anti-nutritive substances showed that among the high protein feeds assessed, raw full-fat soybeans contained the highest amount $\left(20.0 \mathrm{~g} \cdot \mathrm{kg}^{-1}\right)$ of trypsin inhibitors. Extrusion of the above-mentioned components reduced the level of those compounds more than twofold; however, inhibitors were the least numerous in the extracted soybean meal. Analysis of the content of tannins in soybean materials indicated that it was nearly three times lower in extruded soybean than in extracted soybean meal and more than 2.5 times lower than in raw soybean. The amount of tannins in extruded lupine was close to their level in extruded soybean, while DDGS contained amounts similar to those found in extracted soybean meal.

Biological studies demonstrated that extruded soybeans or DDGS used in rations as partial substitutes for extracted soybean meal protein (30\% in starter, and $50 \%$ in grower and finisher rations) contributed to achieving chicken body weights similar to the control group with similar feed consumption in respective rearing periods (Table 3).

A negative effect of raw soybean and extruded lupine on rearing performance was demonstrated. Compared to birds from the control group, the body weight of six-week-old chickens fed with rations containing raw soybean or extruded lupine was lower by $11 \%(\mathrm{P} \leq 0.01)$ and $6 \%(\mathrm{P} \leq 0.05)$ respectively, and the average feed conversion ratio was higher by $190 \mathrm{~g}(\mathrm{P} \leq 0.01)$ and $120 \mathrm{~g}(\mathrm{P}>0.05)$. 
Table 2. Chemical composition of protein feeds

\begin{tabular}{|c|c|c|c|c|c|}
\hline Item & $\begin{array}{c}\text { Extracted } \\
\text { soybean meal }\end{array}$ & $\begin{array}{c}\text { Extruded full-fat } \\
\text { soybean }\end{array}$ & $\begin{array}{c}\text { Raw full-fat } \\
\text { soybean }\end{array}$ & $\begin{array}{l}\text { Extruded } \\
\text { lupine }\end{array}$ & $\begin{array}{c}\text { Distillers } \\
\text { dried grains } \\
\text { with solubles } \\
\text { (DDGS) }\end{array}$ \\
\hline \multicolumn{6}{|l|}{ Basal nutrients (\%): } \\
\hline dry matter & 92.10 & 94.25 & 91.60 & 91.75 & 90.51 \\
\hline crude ash & 6.60 & 4.87 & 4.90 & 4.05 & 3.82 \\
\hline crude protein & 46.58 & 33.79 & 30.55 & 29.52 & 28.29 \\
\hline crude fat & 2.25 & 21.68 & 22.09 & 7.86 & 8.32 \\
\hline crude fibre & 4.70 & 6.70 & 7.50 & 10.00 & 9.87 \\
\hline $\mathrm{N}$-free extractives & 31.97 & 27.21 & 26.56 & 40.32 & 40.21 \\
\hline \multicolumn{6}{|c|}{ anti-nutritional factors $\left(\mathrm{g} \cdot \mathrm{kg}^{-1}\right)$} \\
\hline trypsin inhibitors & 1.2 & 9.0 & 20.0 & - & - \\
\hline tannins & 15.4 & 5.28 & 13.8 & 6.62 & 14.7 \\
\hline \multicolumn{6}{|c|}{ Essential amino acids $\left(\mathrm{g} \cdot 16 \mathrm{~g}^{-1} \mathrm{~N}\right)$ : } \\
\hline lys & 6.35 & 6.69 & 6.94 & 5.76 & 2.91 \\
\hline met + cys & 2.34 & 3.25 & 3.34 & 2.41 & 3.96 \\
\hline met & 1.46 & 2.17 & 1.77 & 0.96 & 2.00 \\
\hline cys & 0.89 & 1.08 & 1.57 & 1.45 & 1.95 \\
\hline thr & 4.04 & 4.05 & 4.12 & 3.73 & 3.71 \\
\hline ile & 4.77 & 4.56 & 4.58 & 4.34 & 3.71 \\
\hline $\operatorname{trp}$ & 1.29 & 1.34 & 1.41 & 1.02 & 0.81 \\
\hline val & 4.96 & 4.79 & 4.81 & 4.27 & 4.88 \\
\hline leu & 8.03 & 7.58 & 7.63 & 7.35 & 11.98 \\
\hline his & 2.58 & 2.55 & 2.61 & 2.69 & 2.39 \\
\hline fhe & 5.20 & 4.85 & 4.91 & 4.13 & 4.98 \\
\hline tyr & 3.61 & 3.49 & 3.63 & 3.13 & 3.68 \\
\hline \multicolumn{6}{|c|}{ Endogenous amino acids $\left(\mathrm{g} \cdot 16 \mathrm{~g}^{-1} \mathrm{~N}\right)$ : } \\
\hline $\arg$ & 7.21 & 7.13 & 7.10 & 9.35 & 4.21 \\
\hline ser & 5.24 & 5.09 & 5.17 & 5.12 & 4.88 \\
\hline gly & 4.19 & 4.14 & 4.19 & 4.17 & 3.53 \\
\hline asp & 12.19 & 11.93 & 12.11 & 11.35 & 6.65 \\
\hline glu & 19.39 & 18.79 & 18.82 & 22.87 & 19.23 \\
\hline ala & 4.51 & 4.44 & 4.55 & 4.00 & 7.07 \\
\hline pro & 5.15 & 4.94 & 4.91 & 4.40 & 8.02 \\
\hline
\end{tabular}

Chicken slaughter analysis (Table 4) showed that extruded full-fat soybean or DDGS used in rations made it possible to obtain an identical dressing percentage of chickens as that of birds in the control group, while raw soybean and extruded lupine significantly $(\mathrm{P} \leq 0.05)$ reduced it. It was observed that such a method of nutrition had no significant effect on chickens' musculature; however, the effect on fat deposition was demonstrated. Birds fed with rations containing raw soybean or DDGS were characterized by a higher $(\mathrm{P} \leq 0.05)$ percentage of skin with subcutaneous fat compared to chickens receiving rations containing extruded lupine. Regardless of the 
type of protein feed substituted for extracted soybean meal in the rations, the amount of abdominal fat in chicken carcasses increased.

Table 3. Rearing results of broiler chickens

\begin{tabular}{|c|c|c|c|c|c|c|}
\hline \multirow{2}{*}{ Item } & \multicolumn{5}{|c|}{ Groups } & \multirow{2}{*}{ SEM } \\
\hline & SBM & EFFS & RFFS & EL & DDGS & \\
\hline \multicolumn{7}{|c|}{ Body weight (g) } \\
\hline 1 day & \multicolumn{5}{|c|}{$47.7 \pm 0.29 *$} & \\
\hline 21 day & $899 \mathrm{~A}$ & $904 \mathrm{~A}$ & $697 \mathrm{C}$ & $783 \mathrm{~B}$ & $870 \mathrm{~A}$ & 19.126 \\
\hline 35 day & $1997 \mathrm{~A}$ & 2049 A & $1740 \mathrm{~B}$ & 1804 B & $2061 \mathrm{~A}$ & 33.349 \\
\hline 42 day & $2564 \mathrm{ABa}$ & $2645 \mathrm{Aa}$ & $2278 \mathrm{Cb}$ & $2409 \mathrm{BCb}$ & $2651 \mathrm{Aa}$ & 37.451 \\
\hline \multicolumn{7}{|c|}{ Feed intake FI (kg) } \\
\hline 1-21 days & $1.10 \mathrm{Aa}$ & $1.11 \mathrm{Aa}$ & $0.96 \mathrm{Bc}$ & $1.02 \mathrm{Bb}$ & $1.14 \mathrm{Aa}$ & 0.016 \\
\hline $22-35$ days & 1.92 & 1.89 & 1.92 & 1.92 & 2.03 & 0.032 \\
\hline $36-42$ days & 1.11 & 1.10 & 1.19 & 1.14 & 1.18 & 0.019 \\
\hline $1-42$ days & 4.13 & 4.10 & 4.07 & 4.08 & 4.35 & 0.057 \\
\hline \multicolumn{7}{|c|}{ Feed conversion ratio FCR $(\mathrm{kg})$} \\
\hline $1-21$ days & $1.30 \mathrm{Bc}$ & $1.29 \mathrm{Bc}$ & $1.48 \mathrm{Aa}$ & $1.40 \mathrm{ABb}$ & $1.39 \mathrm{ABb}$ & 0.019 \\
\hline $22-35$ days & $1.75 \mathrm{ABb}$ & $1.65 \mathrm{Bb}$ & $1.84 \mathrm{Aa}$ & $1.88 \mathrm{Aa}$ & $1.71 \mathrm{ABb}$ & 0.036 \\
\hline 36-42 days & $1.95 \mathrm{ABb}$ & $1.86 \mathrm{ABb}$ & $2.23 \mathrm{Aa}$ & $1.89 \mathrm{Bb}$ & $2.01 \mathrm{ABab}$ & 0.060 \\
\hline 1-42 days & $1.64 \mathrm{Bbc}$ & $1.61 \mathrm{Bc}$ & $1.83 \mathrm{Aa}$ & $1.76 \mathrm{ABab}$ & $1.69 \mathrm{Bbc}$ & 0.026 \\
\hline
\end{tabular}

* - standard deviation (SD).

$\mathrm{A}, \mathrm{B}, \mathrm{C}-$ values in rows with different letters differ significantly $(\mathrm{P} \leq 0.01)$.

$\mathrm{a}, \mathrm{b}, \mathrm{c}-$ values in rows with different letters differ significantly $(\mathrm{P} \leq 0.05)$.

Table 4. Slaughter value of broiler chickens

\begin{tabular}{|c|c|c|c|c|c|c|}
\hline \multirow{2}{*}{ Item } & \multicolumn{5}{|c|}{ Groups } & \multirow{2}{*}{ SEM } \\
\hline & SBM & EFFS & RFFS & EL & DDGS & \\
\hline $\begin{array}{l}\text { Dressing percentage } \\
(\%)\end{array}$ & $75.06 \mathrm{Aa}$ & $74.15 \mathrm{ABab}$ & $71.85 \mathrm{Cc}$ & $73.27 \mathrm{BCb}$ & $74.05 \mathrm{ABab}$ & 0.256 \\
\hline \multicolumn{7}{|c|}{ Share in cold carcass $(\%)$} \\
\hline $\begin{array}{l}\text { Muscles total } \\
\text { including: }\end{array}$ & 53.74 & 52.09 & 53.40 & 53.00 & 52.50 & 0.286 \\
\hline breast & 31.54 & 31.00 & 31.68 & 30.17 & 30.45 & 0.329 \\
\hline thigh & 13.74 & 12.46 & 12.92 & 12.92 & 13.06 & 0.183 \\
\hline drumstick & 8.46 & 8.63 & 8.61 & 8.56 & 8.99 & 0.115 \\
\hline $\begin{array}{l}\text { Skin with subcutane- } \\
\text { ous fat }\end{array}$ & $9.79 \mathrm{ab}$ & $9.69 \mathrm{ab}$ & $10.39 \mathrm{a}$ & $9.41 \mathrm{~b}$ & $10.87 \mathrm{a}$ & 0.227 \\
\hline Abdominal fat & $1.04 \mathrm{Bc}$ & $1.27 \mathrm{ABbc}$ & $1.75 \mathrm{Aa}$ & $1.13 \mathrm{ABbc}$ & $1.55 \mathrm{ABab}$ & 0.077 \\
\hline $\begin{array}{l}\text { Giblets total } \\
\text { including: }\end{array}$ & $4.24 \mathrm{~B}$ & $4.48 \mathrm{AB}$ & $4.78 \mathrm{~A}$ & $4.81 \mathrm{~A}$ & $4.62 \mathrm{AB}$ & 0.068 \\
\hline gizzard & 1.72 & 1.91 & 1.87 & 2.01 & 1.89 & 0.047 \\
\hline liver & $1.88 \mathrm{~b}$ & $2.00 \mathrm{ab}$ & $2.23 \mathrm{a}$ & $2.27 \mathrm{a}$ & $2.14 \mathrm{ab}$ & 0.503 \\
\hline heart & 0.64 & 0.57 & 0.68 & 0.61 & 0.59 & 0.015 \\
\hline
\end{tabular}

$\mathrm{A}, \mathrm{B}, \mathrm{C}-$ values in rows with different letters differ significantly $(\mathrm{P} \leq 0.01)$. $\mathrm{a}, \mathrm{b}, \mathrm{c}-$ values in rows with different letters differ significantly $(\mathrm{P} \leq 0.05)$. 
A significantly $(\mathrm{P} \leq 0.01)$ higher share of total giblets, including liver $(\mathrm{P} \leq 0.05)$, was characteristic of chickens from RFFS and EL groups compared to birds from the control group.

The protein feeds in broiler chicken rations did not affect the acidity of the breast muscle; however its colour was modified (Table 5). Higher $(\mathrm{P}>0.05)$ yellow saturation and degree of saturation $(\mathrm{P} \leq 0.05)$ was demonstrated in the muscles of birds fed with rations containing extruded soybean (EFFS group) compared to the muscle of chickens from the control group.

Table 5. Physical properties of breast muscles

\begin{tabular}{l|c|c|c|c|c|c}
\hline \multirow{2}{*}{ Item } & \multicolumn{5}{c|}{ Groups } & \multirow{2}{*}{ SEM } \\
\cline { 2 - 6 } & SBM & EFFS & RFFS & EL & DDGS & \\
\hline $\mathrm{pH}_{1}$ & 6.27 & 6.22 & 6.27 & 6.18 & 6.19 & 0.026 \\
$\mathrm{pH}_{24}$ & 5.54 & 5.64 & 5.45 & 5.48 & 5.62 & 0.028 \\
WHC (\%) & 13.54 & 12.49 & 13.69 & 13.98 & 12.77 & 1.844 \\
Colour & & & & & & 0.559 \\
L* & 47.54 & 49.40 & 51.17 & 50.65 & 50.42 & 0.165 \\
$\mathrm{a}^{*}$ & 3.51 & 3.15 & 2.93 & 3.36 & 3.24 & 0.308 \\
$\mathrm{~b}^{*}$ & $1.75 \mathrm{ab}$ & $3.59 \mathrm{a}$ & $1.30 \mathrm{~b}$ & $3.04 \mathrm{ab}$ & $2.52 \mathrm{ab}$ & 1.828 \\
$\mathrm{C}=\left(\mathrm{a}^{2}+\mathrm{b}^{2}\right) / 2$ & $7.74 \mathrm{~b}$ & $20.47 \mathrm{a}$ & $7.04 \mathrm{~b}$ & $12.80 \mathrm{ab}$ & $11.66 \mathrm{ab}$ & 0.218 \\
$\mathrm{H}=\log (\mathrm{b} / \mathrm{a})$ & 0.57 & 1.93 & 0.52 & 0.95 & 0.81 & 0.95 \\
\hline
\end{tabular}

$\mathrm{a}, \mathrm{b}-$ values in rows with different letters differ significantly $(\mathrm{P} \leq 0.05)$.

The content of basic nutrients in muscles was not determined by the chicken nutrition method, except for the content of crude fat (Table 6). Lower $(\mathrm{P} \leq 0.05)$ amounts of this component were recorded in the muscles of chickens fed with rations containing extruded lupine compared to chickens from the control group and those fed with extruded soybean.

Table 6. Basal nutrients content $\left(\mathrm{g} \cdot 100 \mathrm{~g}^{-1}\right)$ of breast muscles

\begin{tabular}{l|c|c|c|c|c|c}
\hline \multirow{2}{*}{\multicolumn{1}{c}{ Item }} & \multicolumn{5}{c|}{ Groups } & \multirow{2}{*}{ SEM } \\
\cline { 2 - 6 } & SBM & EFFS & RFFS & EL & DDGS & \\
\hline Dry matter & 25.65 & 25.49 & 25.84 & 25.71 & 25.54 & 0.100 \\
Crude ash & 1.21 & 1.14 & 1.19 & 1.22 & 1.18 & 0.094 \\
Crude protein & 23.07 & 22.94 & 23.38 & 23.42 & 23.14 & 0.040 \\
Crude fat & $1.37 \mathrm{a}$ & $1.31 \mathrm{a}$ & $1.27 \mathrm{ab}$ & $1.07 \mathrm{~b}$ & $1.21 \mathrm{ab}$ & 0.051 \\
\hline
\end{tabular}

$\mathrm{a}, \mathrm{b}-$ values in rows with different letters differ significantly $(\mathrm{P} \leq 0.05)$.

The dietary value of chicken meat also depends on the fatty acids profile modified as a result of using rations that contain different protein feeds (Table 7). The elimination of extracted soybean meal from rations and adding other protein feeds had an impact on reducing the level of saturated fatty acids (SFA), and it increased 
UFA, including PUFA, in lipids of the analysed muscles $(\mathrm{P} \leq 0.01)$. Compared to the muscles of chicken in the SBM and DDGS groups, the muscles of birds on extruded or raw soybean and extruded lupine diets contained significantly $(\mathrm{P} \leq 0.01)$ more most valuable, $n-3$ polyunsaturated fatty acids (PUFA). In terms of nutrition, the most beneficial ratio of $n-3: n-6$ acids was observed in the muscles of chickens receiving extruded or raw soybean and extruded lupine.

Table 7. Fatty acids profile ( $\%$ of total fatty acids) in breast muscles

\begin{tabular}{|c|c|c|c|c|c|c|}
\hline \multirow{2}{*}{ Item } & \multicolumn{5}{|c|}{ Groups } & \multirow{2}{*}{ SEM } \\
\hline & SBM & EFFS & RFFS & EL & DDGS & \\
\hline $\mathrm{C} 14: 0$ & $0.470 \mathrm{a}$ & $0.472 \mathrm{a}$ & $0.395 \mathrm{ab}$ & $0.287 \mathrm{~b}$ & $0.367 \mathrm{ab}$ & 0.022 \\
\hline $\mathrm{C} 14: 1 n-5$ & $0.071 \mathrm{a}$ & $0.063 \mathrm{ab}$ & $0.020 \mathrm{bc}$ & $0.001 \mathrm{c}$ & $0.019 \mathrm{bc}$ & 0.008 \\
\hline $\mathrm{C} 15: 0$ & 0.091 & 0.108 & 0.108 & 0.091 & 0.090 & 0.004 \\
\hline $\mathrm{C} 16: 0$ & $18.471 \mathrm{Aa}$ & $17.094 \mathrm{ABb}$ & $16.139 \mathrm{Bb}$ & $14.007 \mathrm{Cc}$ & $16.254 \mathrm{Bb}$ & 0.410 \\
\hline $\mathrm{C} 16: 1 n-7$ & 2.030 & 1.394 & 1.473 & 1.090 & 1.515 & 0.128 \\
\hline $\mathrm{C} 17: 0$ & 0.182 & 0.216 & 0.207 & 0.201 & 0.191 & 0.007 \\
\hline $\mathrm{C} 17: 1 n-7$ & 0.101 & 0.097 & 0.089 & 0.088 & 0.087 & 0.002 \\
\hline $\mathrm{C} 18: 0$ & $6.964 \mathrm{a}$ & $7.219 \mathrm{a}$ & $6.774 \mathrm{a}$ & $5.731 \mathrm{~b}$ & $5.800 \mathrm{~b}$ & 0.200 \\
\hline $\mathrm{C} 18: 1 n-9$ & $31.395 \mathrm{a}$ & $27.481 \mathrm{~b}$ & $27.533 \mathrm{~b}$ & $28.416 \mathrm{~b}$ & $28.990 \mathrm{~b}$ & 0.479 \\
\hline $\mathrm{C} 18: 2 n-6$ & $33.762 \mathrm{Bc}$ & $38.404 \mathrm{Ab}$ & $39.345 \mathrm{Aab}$ & $42.640 \mathrm{Aa}$ & $40.380 \mathrm{Aab}$ & 0.872 \\
\hline $\mathrm{C} 18: 3 n-6$ & 0.267 & 0.253 & 0.282 & 0.290 & 0.281 & 0.006 \\
\hline $\mathrm{C} 18: 3 n-3$ & $2.975 \mathrm{~B}$ & $4.161 \mathrm{~A}$ & $4.114 \mathrm{~A}$ & $4.094 \mathrm{~A}$ & $3.030 \mathrm{~B}$ & 0.149 \\
\hline $\mathrm{C} 20: 0$ & $0.105 \mathrm{~b}$ & $0.122 \mathrm{ab}$ & $0.119 \mathrm{ab}$ & $0.131 \mathrm{a}$ & $0.130 \mathrm{a}$ & 0.003 \\
\hline C20:1n-15 & 0.080 & 0.088 & 0.108 & 0.076 & 0.116 & 0.006 \\
\hline $\mathrm{C} 20: 1 n-9$ & $0.276 \mathrm{a}$ & $0.221 \mathrm{c}$ & $0.232 \mathrm{bc}$ & $0.233 \mathrm{bc}$ & $0.270 \mathrm{ab}$ & 0.007 \\
\hline $\mathrm{C} 20: 2 n-6$ & 0.381 & 0.373 & 0.430 & 0.322 & 0.374 & 0.013 \\
\hline $\mathrm{C} 20: 3 n-6$ & $0.394 \mathrm{a}$ & $0.402 \mathrm{a}$ & $0.403 \mathrm{a}$ & $0.312 \mathrm{~b}$ & $0.310 \mathrm{~b}$ & 0.014 \\
\hline $\mathrm{C} 20: 4 n-6$ & 1.501 & 1.336 & 1.640 & 1.451 & 1.375 & 0.061 \\
\hline $\mathrm{C} 20: 5 n-3$ & $0.072 \mathrm{ab}$ & $0.084 \mathrm{a}$ & $0.093 \mathrm{a}$ & $0.068 \mathrm{ab}$ & $0.057 \mathrm{~b}$ & 0.003 \\
\hline $\mathrm{C} 22: 0$ & 0.116 & 0.084 & 0.074 & 0.073 & 0.064 & 0.006 \\
\hline $\mathrm{C} 22: 2 n-6$ & $0.021 \mathrm{~b}$ & $0.047 \mathrm{a}$ & $0.001 \mathrm{c}$ & $0.034 \mathrm{ab}$ & $0.021 \mathrm{~b}$ & 0.012 \\
\hline $\mathrm{C} 22: 6 n-3$ & 0.153 & 0.157 & 0.226 & 0.228 & 0.114 & 0.016 \\
\hline Others & 0.122 & 0.124 & 0.195 & 0.136 & 0.136 & 0.006 \\
\hline SFA & $26.399 \mathrm{Aa}$ & $25.315 \mathrm{ABa}$ & $23.816 \mathrm{BCb}$ & $20.521 \mathrm{Dc}$ & $22.896 \mathrm{Cb}$ & 0.570 \\
\hline UFA & $73.479 \mathrm{D}$ & $74.561 \mathrm{DC}$ & $75.989 \mathrm{BC}$ & $79.343 \mathrm{~A}$ & $76.939 \mathrm{~B}$ & 0.769 \\
\hline MUFA & $33.953 \mathrm{a}$ & $29.344 \mathrm{~b}$ & $29.455 \mathrm{~b}$ & $29.904 \mathrm{~b}$ & $30.997 \mathrm{ab}$ & 0.594 \\
\hline PUFA & $39.526 \mathrm{Bc}$ & 45.217 Ab & $46.53 \mathrm{Aab}$ & $49.439 \mathrm{Aa}$ & 45.942 Aab & 0.969 \\
\hline$n-3$ & $3.200 \mathrm{~B}$ & $4.402 \mathrm{~A}$ & $4.433 \mathrm{~A}$ & $4.390 \mathrm{~A}$ & $3.201 \mathrm{~B}$ & 0.162 \\
\hline$n-6$ & $36.326 \mathrm{Bc}$ & $40.815 \mathrm{ABa}$ & $42.101 \mathrm{Aab}$ & $45.049 \mathrm{Aa}$ & $42.741 \mathrm{Aab}$ & 0.873 \\
\hline$n-9$ & $31.671 \mathrm{a}$ & $27.702 \mathrm{~b}$ & $27.765 \mathrm{~b}$ & $28.649 \mathrm{~b}$ & $29.260 \mathrm{ab}$ & 0.484 \\
\hline$n-6: n-3$ & $11.35 \mathrm{~B}$ & $9.27 \mathrm{D}$ & $9.50 \mathrm{D}$ & $10.26 \mathrm{C}$ & $13.35 \mathrm{~A}$ & 0.404 \\
\hline
\end{tabular}

A, B, C-values in rows with different letters differ significantly $(\mathrm{P} \leq 0.01)$.

$\mathrm{a}, \mathrm{b}$ - values in rows with different letters differ significantly $(\mathrm{P} \leq 0.05)$. 
The introduction of the analysed protein materials into rations for broiler chickens did not affect the sensory values of breast muscles (Table 8).

Table 8 . Results of sensory evaluation of breast muscle (points)

\begin{tabular}{l|c|c|c|c|c|c}
\hline \multirow{2}{*}{\multicolumn{1}{c}{ Item }} & \multicolumn{5}{c|}{ Groups } & \multirow{2}{*}{ SEM } \\
\cline { 2 - 6 } & SBM & EFFS & RFFS & EL & DDGS & \\
\hline Flavour & 4.18 & 4.45 & 4.10 & 4.18 & 4.00 & 0.017 \\
Juiciness & 4.50 & 4.07 & 4.07 & 4.21 & 4.21 & 0.017 \\
Tenderness & 4.79 & 4.36 & 4.14 & 4.43 & 4.50 & 0.021 \\
Palatability & 4.79 & 4.29 & 4.29 & 4.64 & 4.54 & 0.014 \\
Mean of traits & 4.57 & 4.29 & 4.15 & 4.37 & 4.31 & 0.019 \\
\hline
\end{tabular}

In histological evaluation the liver proved normal and was of similar build in all chickens. The microscopic image of the liver stained with hematoxylin and eosin (Figure 1) showed the lobules separated by fragile connective tissue, visible trabecular structures irregularly radiating towards the central vein. Hepatic cells are generally mononuclear and contain evenly distributed basophilic granules in the cytoplasm. A small number of Borowicz-Kupfer cells were observed between the hepatocytes' trabeculae. The peripheral zone of the lobules contained portal tracts with the artery and hepatic vein and the bile duct and ramifications. Insignificant amounts of neutral fats in the form of very fine vacuoles in individual hepatic cells located mainly in the peripheral zone of the lobules in the vicinity of the portal tract are visible in Figures 2 and 3. No retrogressive changes were observed in those cells. A small accumulation of fine lipid vacuoles was observed in the epithelial cells of bile ducts of the portal tract and the blood vessel wall (Figure 2).

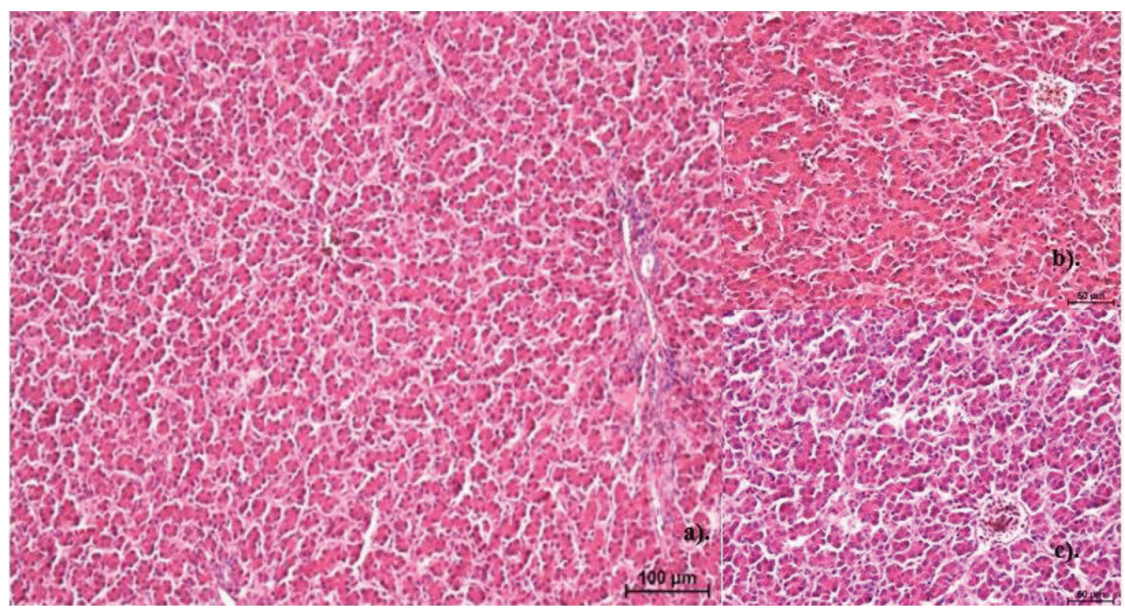

Figure 1. Histological image of chicken liver, hematoxylin and eosin staining. a) Proper histological structure of the liver. Magnification 100x. b) Hepatic lobules with radially hepatocytic beams that radiate towards the central vein. Magnification 200x. c) Single, small cytoplasmic vacuoles in a few hepatocytes. Magnification 200x 


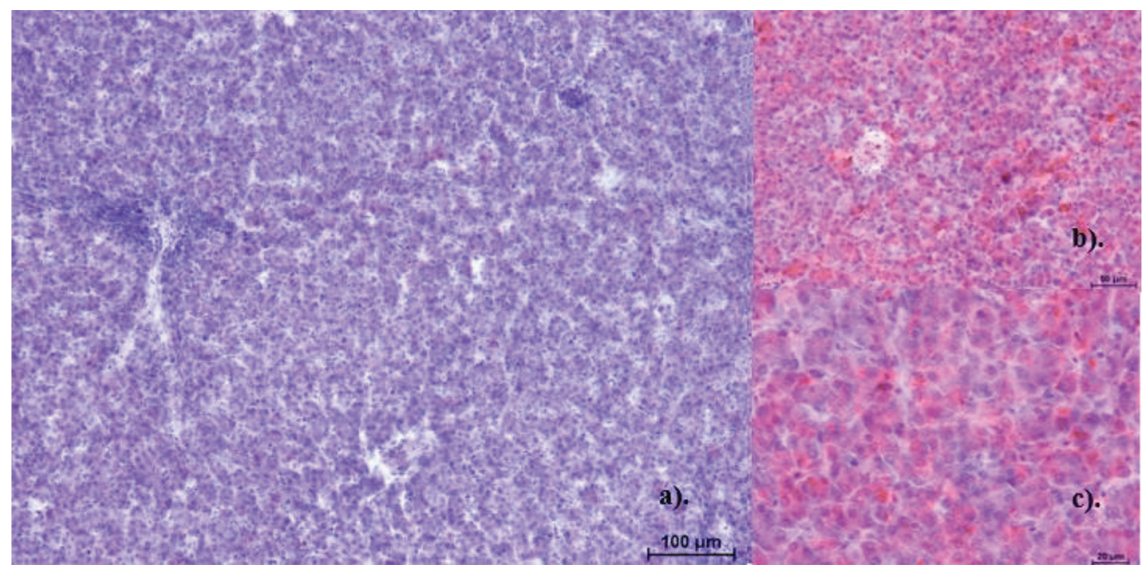

Figure 2. Histological image of chicken liver, Sudan IV and hematoxylin staining. a) Liver of birds from the control group. In the peripheral zone of hepatic lobules in hepatocytes adjacent to the portalgall-space, there are few small lipid drops. Magnification 100x. b) Reaction to the presence of neutral fats in the form of sudanophilic fine and slightly larger vacuoles in the intermediate cytoplasm and peripheral lobar zone. Magnification 200x. c) Sudanophilic bodies in the cytoplasm of hepatocytes of chicken group. Magnification 400x

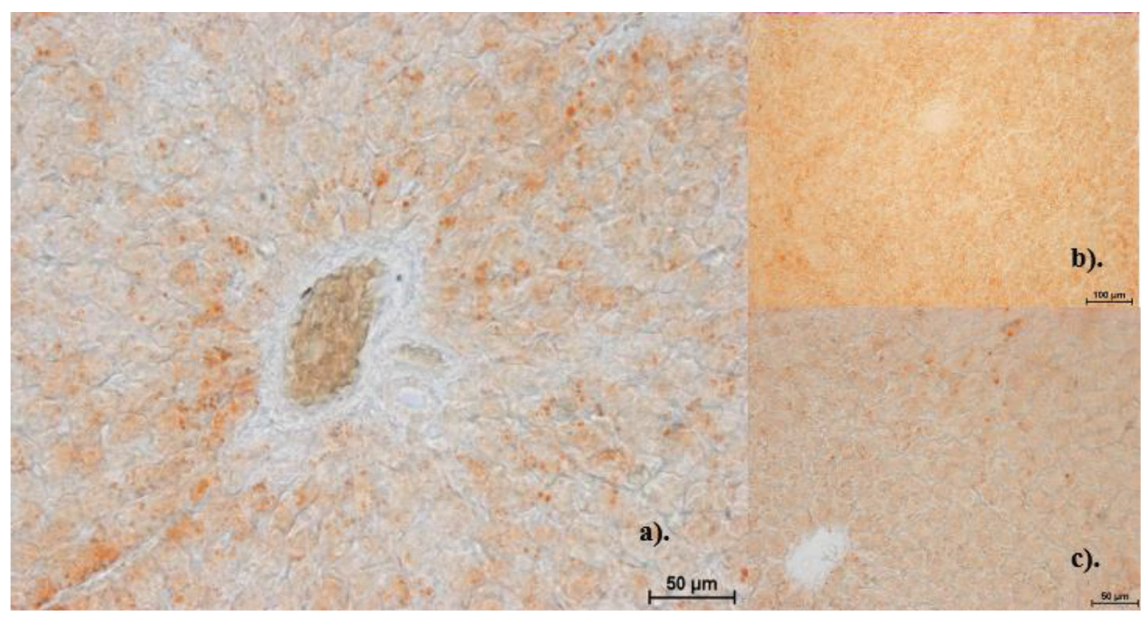

Figure 3. Histological image of the liver of broiler chickens, Sudan IV staining. a) The cytoplasm of single hepatocytes contains small lipid vacuoles. Magnification 200x. b) Small-scale deposits of sudanophilic bodies in the cytoplasm of liver cells in EL group chickens. Magnification 100x. c) Small-scale deposits of sudanophilic bodies in the cytoplasm of liver cells with a slight intensity of reaction in the peripheral zone of the lobule (DDGS group). Magnification 200x

\section{Discussion}

The content of the basic components determined in our research in both extracted soybean meal and raw soybean was similar to values specified by the Standards 
and Recommendations of Poultry Nutrition (2005) and in the Tables of chemical composition and nutritive value of feed (2015). Amounts of respective amino acids in extracted soybean meal and raw soybean were similar to average values given in the above-mentioned sources. In extruded lupine, a lower content of total protein (by 5.92\%) and crude fat $(2.12 \%)$ were determined in comparison to the results of the study by Diaz et al. (2006). Rutkowski et al. (2016) also mention higher protein content in extruded lupine. However, it contained less lysine, threonine, valine, isoleucine and leucine. The content of basic components and amino acids in DDGS fell within the limits specified by Alaeldein et al. (2017). Some researchers (Świątkiewicz and Koreleski, 2008; Salim et al., 2010) emphasize that DDGS is characterized by high variability in the nutritive value of different varieties, production year, level of converting starch to ethanol, duration, and temperature of the drying process.

Previous studies (Leontowicz et al., 1999; Egounlety and Aworh, 2003; Berger et al., 2015; Clarke and Wiseman, 2007; Loeffler et al., 2013; Jahanian and Rasouli, 2016) showed that the content of anti-nutritional substances in soybean products depended on the variety of soybean and applied purification treatments. As regards trypsin inhibitors, it was demonstrated that heating reduced the amount of these compounds to the greatest extent. Our research showed that soybean contained the highest amount of trypsin inhibitors and those amounts were lower (23-60 TUI $\mathrm{mg}^{\cdot} \mathrm{g}^{-1}$ ) than those determined by Leontowicz et al. (1999), Egounlety and Aworh (2003) and Berger et al. (2015). Extrusion of full-fat raw soybean reduced the level of these antinutrients more than twice; however, the lowest amount was found in extracted soybean meal. The content of trypsin inhibitors in extracted soybean meal analysed by Loeffler et al. (2013) and Woyengo et al. (2016) was, however, significantly higher (2.25-3.1 TUI $\left.\cdot \mathrm{g}^{-1}\right)$. Studies by other authors (Clarke and Wiseman, 2007; Loeffler et al., 2013) confirm the beneficial effect of temperature on the amount of these substances. Clarke and Wiseman (2007) report that the content of trypsin inhibitors in extruded full-fat soybean decreased proportionately to the rise in temperature $(90$, 110,130 and $160^{\circ} \mathrm{C}$ ): $14.8 ; 9.6 ; 4.5$ and $1.9 \mathrm{mg} \cdot \mathrm{g}^{-1}$. Loeffler et al. (2013) also demonstrated that the content of these compounds was lower $\left(27.20 \mathrm{TUI} \cdot \mathrm{g}^{-1}\right)$ in heated extruded beans than in unheated ones $\left(46.10 \mathrm{TUI} \cdot \mathrm{g}^{-1}\right)$, regardless of soybean variety. In the heated extruded soybean of a variety having a reduced content of trypsin inhibitors, more than three times less $\left(5.0 \mathrm{TUI} \cdot \mathrm{g}^{-1}\right)$ of these substances were found compared to unheated extruded beans $\left(16.0 \mathrm{TUI} \cdot \mathrm{g}^{-1}\right)$.

Analysing the content of tannins in the examined soybean materials, it was found that not only temperature, but humidity and pressure significantly reduced the level of these compounds, as extruded soybean contained almost 3 times less of them than extracted soybean meal did and more than 2.5 times less than raw soybean. Other researchers (Egounlety and Aworh, 2003; Toledo et al., 2007) observed a reduction in tannins in extruded soybean. Toledo et al (2007), analysing the content of these compounds in 5 soybean varieties, found that their amount decreased from $0.28-0.39 \mathrm{mg} \cdot \mathrm{g}^{-1}$ in raw soybean to $0.16-0.27 \mathrm{mg} \cdot \mathrm{g}^{-1}$ in extruded soybean. According to Egounlety and Aworh (2003), soaking soybean also reduced the level of tannins, as the analysis carried out by the above mentioned authors demonstrated that soaked 
beans contained approximately 54\% less of these substances than raw ones did (1.52 $\mathrm{mg} \cdot \mathrm{g}^{-1} \mathrm{~d}$.m.).

Obtaining similar body weights and feed conversion ratios for the control group for birds fed with rations containing extruded soybean as a partial substitute for the extracted soybean meal protein is consistent with the results of Jahanian and Rasouli (2016). The authors demonstrated no differences in the above-mentioned rearing parameters of six-week-old chickens; however, in the rations fed to them, extracted soybean meal was substituted in full by extruded full-fat soybean. A significant reduction in the weight of chickens, however only from days 1 to 10 of their life, after introducing $15 \%$ of extruded soybeans into their diets, was observed by Zhaleh et al. (2014). Unfavourable results of the present authors' studies concerning the production performance of chickens fed with rations containing raw soybean should be attributed to the high content of anti-nutrients, as according to Clarke and Wiseman (2007), a reduction in trypsin inhibitors to approximately $4 \mathrm{mg} \cdot \mathrm{g}^{-1}$ in complete rations has a positive impact on broiler chickens. A reduction (by $40-65 \%$ ) of body weight gain and feed intake by chickens after replacing extracted soybean meal with full-fat soybean as the main source of protein in rations was demonstrated by Olkowski et al. (2016). Similarly, as the amount of raw full-fat soybean in the chicken diets increased, Erdaw et al. (2018) observed a decrease in BWG and FI values. Studies by the present authors also demonstrated a negative impact of rations containing extruded lupine on chicken rearing rates. Rutkowski et al. (2016) assume that the form of lupine (raw or extruded) does not affect BWG, but the percentage content of lupine doses, as the use of 10 or $20 \%$ has no effect on body weight, while 25 or $30 \%$ reduces it. Lower performance of birds could be connected with the presence of anti-nutrients as lupine contains relatively high levels of non-starch polysaccharides (NSP). NSP reduce digestibility of nutrients as well as increased digesta viscosity. A large discrepancy can be observed comparing the production performance obtained in the studies involving chickens fed with rations containing DDGS with the results of other authors (Świątkiewicz and Koreleski, 2008; Lumpkins et al., 2004; Lukaszewicz and Kowalczyk, 2014; Sariozkan et al., 2015; Mir et al., 2018). Lukaszewicz and Kowalczyk (2014) report that 5\% of DDGS included in rations for chickens does not reduce the rearing performance; however, a higher percentage (10 or 15\%) of this feed reduces BWG and increases FCR. On the other hand Mir et al. (2018) demonstrated that $5 \%$ or $10 \%$ of DDGS rations has no effect on the weight of 42-day-old chickens, but it significantly increases feed intake and conversion rate. Lumpkins et al. (2004) claimed a significant reduction in final body weight of chickens fed with rations containing $18 \%$ of DDGS. In contrast, Sariozkan et al. (2015) assume that an inclusion of even up to $30 \%$ of this feed in a diet does not affect chicken rearing performance.

Jahanian and Rasouli (2016) did not observe any influence of extruded soybean in the rations on the dressing percentage of chickens either. In contrast, Wang et al. (2007) demonstrated that $15 \%$ of DDGS added to rations for broiler chickens reduced the dressing percentage. On the other hand, Świątkiewicz and Koreleski (2003) noted a significant increase in the value of this parameter after adding 5 or $10 \%$ of this feed. Lukasiewicz and Kowalczyk (2014), Jiang et al. (2014) and Shim 
et al. (2018) did not find any effect of DDGS (5, 10, 15 or 20\%) in rations on the dressing percentage, and chickens' musculature and fat deposition. In studies by the present authors, birds fed with rations containing DDGS or raw soybean had a significantly $(\mathrm{P} \leq 0.05)$ higher percentage of skin with subcutaneous fat compared to chickens receiving rations containing extruded lupine. Replacing extracted soybean meal in rations containing various protein feeds (EFFS, RFFS, EL, and DDGS groups) resulted in an increase in the percentage of fat in chickens' carcasses. A significant $(\mathrm{P}<0.05)$ increase in abdominal fat proportion in the carcass after replacing extracted soybean meal with extruded soybean in rations for chickens was observed by Jahanian and Rasouli (2016). Shim et al. (2018) did not show an influence of DDGS in diets for broilers on their fat deposition.

A higher $(\mathrm{P} \leq 0.01)$ proportion of total giblets, including liver $(\mathrm{P} \leq 0.05)$, was characteristic of chickens from RFFS and EL groups compared to birds from the control group (SBM). No effect of extruded soybean in rations for broiler chickens on the proportion of stomach in the carcasses is consistent with the results of Pacheco et al. (2014). Similarly, Lukasiewicz and Kowalczyk (2014) did not observe any effect of 5,10 or $15 \%$ of DDGS in rations for chickens on their weight and on the proportion of edible giblets. In contrast, Sariozkan et al. (2015) report that even up to $30 \%$ of this feed material in chicken diets has no impact on the birds' internal organs.

The lack of effect of DDGS in rations for chickens on the acidity of breast muscles is consistent with the results obtained by Corzo et al. (2009), Lukasiewicz and Kowalczyk (2014), Jiang et al. (2014) and Shim et al. (2018). Mir et al. (2018) assume that 5 or $10 \%$ of DDGS added to rations for chickens significantly increase the $\mathrm{pH}$ and colour brightness of meat. Lukasiewicz and Kowalczyk (2014) also claim that DDGS in chicken diets differentiates meat colour brightness; its smallest value (56.5) was observed in the muscles of cockerels fed with rations containing $15 \%$ of DDGS, and the largest value (61.2) in cocks from the control group (SBM).

Jiang et al. (2014) observed no effect of $15 \%$ of DDGS in the ration on the content of fat in the chicken breast muscle, while Lukasiewicz and Kowalczyk (2014) observed a significant effect of 5, 10 or $15 \%$ of DDGS in rations on the content of dry matter, crude protein and crude fat in the examined broiler chicken muscles. The authors found a favourable reduction in the crude fat content in the breast muscles of both sexes, except for the muscles of cocks fed with the rations containing $15 \%$ of DDGS.

The dietary value of chicken meat depends on the fatty acid (FA) profile that has been modified under the influence of protein materials used in rations. The highest content of linoleic acid in the chicken muscles from EL group should be associated with a high share (90\%) of UFA, especially C18:1 and C18:2, in Lupinus spp. (Mohamed and Rayas-Duarte, 1995; Nossacka et al., 2000; Rybiński et al., 2018). The results of studies of the present authors are consistent with results obtained by Jiang et al. (2014) and Shim et al. (2018). After introducing DDGS into rations for chickens, the authors observed a reduction $(\mathrm{P}<0.05)$ in $\mathrm{C} 16: 0, \mathrm{C} 18: 0$, SFA and MUFA levels, and an increase $(\mathrm{P}<0.05)$ in $\mathrm{C} 18: 2$ and PUFA. A significant reduction in the sum of saturated fatty acids in favour of UFA, and an increase in $n-3$ and $n-6$ PUFA in them after adding DDGS to chicken diets is also reported by Mir et al. (2018). It is 
evident in reference literature that the fatty acid profile of feed is the most important determinant of the fatty acid profile of meat (Cortinas et al., 2004; Su et al., 2013).

The examined protein materials in rations for broiler chickens did not change the sensory values of breast muscles. Corzo et al. (2009) did not find any effect of DDGS in rations for chickens on the sensory properties of muscles either.

Livers of broiler chickens are organs that are particularly susceptible to morphological changes, which should probably be associated with intense hepatic metabolism (Szarek et al., 2000). No inflammatory lesions were found in the examined poultry livers. Staining for neutral fat presence revealed no significant differences between groups with regard to number and distribution. Only a slight increase in the number of lipids in EL and DDGS groups was found. This may have resulted from disturbing the lipid metabolism described as simple steatosis (without cell damage). Small differences in the quantities of neutral fat should be considered falling within the limits of physiological norms, as none of the groups revealed any retrogressive changes in the form of degeneration or necrosis. No significant lesions in liver histology may be associated with a short (six-week) period of intake of feeds containing anti-nutritional substances (e.g. tannins, trypsin inhibitors) and their amounts that may have a negative impact on the macro- and microscopic image of broiler chickens' internal organs. Hyperaemia and degeneration of hepatic cells after the addition of approximately $16 \mathrm{~g} \cdot \mathrm{g}^{-1}$ of tannins into rations for broiler chickens was reported by Emiola et al. (2007).

The results of researches carried out form a basis to recommend using extruded full-fat soybean or DDGS in rations for broiler chickens, as partial (30\% in starter, and $50 \%$ in grower and finisher rations) substitutes of extracted soybean meal protein since they result in a production and slaughter results similar to those of chickens from the control group. Raw soybean or extruded lupine introduced to birds' diets have a negative effect on most of the evaluated parameters.

\section{References}

A 1 a e ld e in M.A., R a ed M.A., R if a t U.K. (2017). A survey of mycotoxin contamination and chemical composition of distiller's dried grains with solubles (DDGS) imported from the USA into Saudi Arabia. Environ Sci. Pollut. Res., 24: 15401-15405.

AOAC (1990). Official Methods of Analysis of the Association of Official Analytical Chemists, 15 th Ed. Chapter 32. Washington, DC.

B a r y $\nmid$ k o - P i k i e ln a N., M a t u s z e w s k a I. (2014). Sensory Analysis of Food: Basics - Methods Applications (in Polish). Wyd. II. Wyd. Nauk. PTTZ, Kraków, 375 pp.

B erger M., P a u la is A., Nourbakhsh-Rey M., Rooryck S., Labalette F., Maury P. (2015). Trypsin inhibitors in soybean seed: evaluation of genotypic variability in a core collection, effect of very early sowing and reduced irrigation. OCL - Oilseeds and fats Crops and Lipids, 22; Doi: $10.1051 / \mathrm{ocl} / 2015037$.

Chatzifragkou A., Kosik O., Prabhakumari P.C., Lovegrove A., Frazier R.A., Shewry P.R., Chara la m p p oulos D. (2015). Biorefinery strategies for upgrading distillers' dried grains with solubles (DDGS). Process Biochem., 50: 2194-2207.

C l a r k e E., W is e m a n J. (2007). Effects of extrusion conditions on trypsin inhibitor activity of full fat soybeans and subsequent effects on their nutritional value for young broilers. Brit. Poultry Sci., 48: 703-712. 
Commission Regulation (EC) (2009). High performance liquid chromatography method with fluorescence detection (HPLC-FLD). No 152/2009 (Annex III, G).

Cortina s., Villaverd e C., Gal obart J., B a u c ells M.D., Cod ony R., B a r roet a A.C. (2004). Fatty acid content in chicken thigh and breast as affected by dietary polyunsaturation level. Poultry Sci., 83: 1155-1164.

Corzo A., Schilling M.W., Loar R.E. II, Jackson V., Kin S., Radhakrishman V. (2009). The effects of feeding distillers dried grains with solubles on broiler meat quality. Poultry Sci., 88: 432-439.

Diaz D., Morlacchini M., Masoero M., Mos chini M., Fusconi G., Piva G. (2006). Pea seeds (Pisum sativum), faba beans (Vicia faba var. minor) and lupin seeds (Lupinus albus var. multitalia) as protein sources in broiler diets: effect of extrusion on growth performance. Ital. J. Anim. Sci., 5: 43-53.

D o m in g o J.L., B o r d o n a b a J.G. (2011). A literature review on the safety assessment of genetically modified plants. Environ. Int., 37: 734-742.

Dzuman Z., Stranska-Zachariasova M., Vaclavikova M., Tomaniova M., Veprikova Z., Slavikova P., Hajs lova J. (2016). Fate of free and conjugated mycotoxins within the production of distiller's dried grains with solubles (DDGS). J. Agric. Food Chem., 64: 5085-5092.

E g o un let y M., Aw or h O.C. (2003). Effect of soaking, dehulling, cooking and fermentation with Rhizopus oligosporus on the oligosaccharides, trypsin inhibitor, phytic acid and tannins of soybean (Glycine max Merr.), cowpea (Vigna unguiculata L. Walp) and groundbean (Macrotyloma geocarpa Harms). J. Food Eng., 56: 249-254.

E m i o la I.A., O log h ob o A.D., G o u s R.M. (2007). Performance and histological responses of internal organs of broiler chickens fed raw, dehulled, and aqueous and dry-heated kidney bean meals. Poultry Sci., 86: 1234-1240.

Erdaw M.M., P erez-Mald on ado R.A., Iji P.A. (2018). Physiological and health-related response of broiler chickens fed diets containing raw, full-fat soya bean meal supplemented with microbial protease. J. Anim. Physiol. Anim. Nutr., 102: 533-544.

Gra u R., H a m m R. (1953). Eine einfache Methode zur Bestimmung der Wasserbindung im Muskel. Naturwissenschaften, 40, 29.

He L., W u H., Chen W., Meng Q., Z h o u Z. (2017). Influence of sulfur on the fermentation characteristics of corn distiller's dried grains with solubles in in vitro culture. Czech J. Anim. Sci., 62: $417-425$.

Jahanian R., R a s o uli E. (2016). Effect of extrusion processing of soybean meal on ileal amino acid digestibility and growth performance of broiler chicks. Poultry Sci., 95: 2871-2878.

J i a n g W., N i e S., Qu Z., B i C., S h a n A. (2014). The effects of conjugated linoleic acid on growth performance, carcass traits, meat quality, antioxidant capacity, and fatty acid composition of broilers fed corn dried distillers grains with solubles. Poultry Sci., 93: 1202-1210.

Leontowicz H., Le ontowicz M., Kostyra H., Gralak M.A., Kulasek G.W. (1999). The influence of extrusion or boiling on trypsin inhibitor and lectin activity in leguminous seeds and protein digestibility in rats. Pol. J. Food. Nutr. Sci., 8: 77-87.

L o effle r T., Shim M.Y., B eckstead R.B., B atal A.B., P e sti G.M. (2013). Amino acid digestibility and metabolizable energy of genetically selected soybean products. Poultry Sci., 92: $1790-1798$.

Lukaszew ic z E., Kow a lczyk A. (2014). Slaughter yield and breast meat quality of chicken broilers in relation to sex and level of dietary maize distillers dried grains with solubles (DDGS). Revue Méd. Vét., 165: 176-182.

L u m p k in s B.S., B a t a 1 A.B., D a le N.M. (2004). Evaluation of distillers dried grains with solubles as a feed ingredient for broilers. Poultry Sci., 83: 1891-1896.

M i l c zarek A., O s e k M. (2016). Partial replacement of soya bean with low-tannin faba bean varieties (Albus or Amulet): effects on growth traits, slaughtering parameters and meat quality of Puławska pigs. Ann. Anim. Sci., 16: 477-487.

Mir N.A., Tyag i P.K., B is w a s A.K., Tyag i P.K., Manda 1 A.B., Kumar F., Sharma D., B is w a s A. (2018). Inclusion of flaxseed, broken rice, and distillers dried grains with solubles (DDGS) in broiler chicken ration alters the fatty acid profile, oxidative stability, and other functional properties of meat. Eur. J. Lipid Sci. Technol., 120; https://doi.org/10.1002/ejlt.201700470. 
Mohamed A.A., Ray a s - D u a r te P. (1995). Composition of Lupinus albus. Cereal Chem., 72: 643-647.

Moschini M., Masoero F., Prandini A., Fusconi G., Morlacchini M., Piva G. (2005). Raw Pea (Pisum sativum) raw Faba bean (Vicia faba var. minor) and raw Lupin (Lupinus albus var. multitalia) as alternative protein sources in broiler diets. Ital. J. Anim. Sci., 4: 59-69.

No s s a c k a A.C., Vi le ga s a J.H.Y., v o n B a e r b D., L a n c a s a F.M. (2000). Supercritical fluid extraction and chromatographic analysis (HRGC-FID and HRGC-MS) of Lupinus spp. alkaloids. J. Braz. Chem. Soc., 11: 495-501.

Olkowski B., Charuta A., Radzki R., B ienko M., Toczko R. (2016). Skeletal response to diet with soya bean seeds used as primary source of protein in growing broiler chickens. J. Anim. Physiol. Anim. Nutr. 100: 731-737.

P a ch e c o W.J., S t a r k C.R., F e rk et P.R., B r a k e J. (2014). Effects of trypsin inhibitor and particle size of expeller-extracted soybean meal on broiler live performance and weight of gizzard and pancreas. Poultry Sci., 93: 2245-2252.

P alli y e g u r u M.W.C.D., R o s e S.P., M a c k en zi e A.M. (2011). Effect of trypsin inhibitor activity in soya bean on growth performance, protein digestibility and incidence of sub-clinical necrotic enteritis in broiler chicken flocks. Brit. Poult. Sci., 52: 359-367.

P o hj a M.S., Ni in iv a r a F.P. (1957). Die Bestimmung der Wasserbindung des Fleisches mittels der Konstantdruckmethode. Fleischwirtschaft. 9: 193-195.

R e cknage 1 J. (2015). Le soja local en Allemagne, une demande soutenue, une offre qui s'étoffe. OCL - Oilseeds and fats Crops and Lipids, 22: D508.

Rutkows ki A., Kaczmarek S.A., Hejdysz M., Ja mroz D. (2016). Effect of extrusion on nutrients digestibility, metabolizable energy and nutritional value of yellow lupine seeds for broiler chickens. Ann. Anim. Sci., 16: 1059-1072.

Rybiński W., Święcicki W., Bocianowski J., Borner A., Starzycka-Korbas E., S t a r z y c k i M. (2018). Variability of fat content and fatty acids profiles in seeds of a Polish white lupin (Lupinus albus L.) collection. Genet. Resour. Crop Evol., 65: 417-431.

$\mathrm{S}$ a 1 i m H.M., K r u k Z.A., L e e B.D. (2010). Nutritive value of corn distillers dried grains with solubles as an ingredient of poultry diets: a review. World Poultry Sci. J., 66: 411-432.

Sariozkan S., Konca Y., Guclu B.K., Kara K., Ildiz N., Kirkpinar F., B e yzi S.B., Kaliber M. (2015). Effects of dietary supplementation of dried distillers grain with solubles (DDGS) and yucca (Yucca schidigera) on broiler performance, carcass traits, intestinal viscosity and marketing. J. Poultry Res., 12: 5-11.

Sh i m Y.H., K i m J.S., Ho s s e in d o u s t A., Ch o i Y.H., K i m M.J., O h S.M., Ha m H. B., Ku mar A., K i m K.Y., J ang A., C h a e B.J. (2018). Investigating meat quality of broiler chickens fed on heat processed diets containing corn distillers dried grains with solubles. Korean J. Food Sci. Anim. Resour., 38: 629-635.

Smith C., Van Megen W., Twa 1 fhoven L, Hitchcock C. (1980). The determination of trypsin inhibitor levels in foodstuffs. J. Sci. Food Agric., 31: 341-350.

Standards and Recommendations of Poultry Nutrition (2005). Recommended allowances and nutritive value of feedstuffs. In: Poultry Feeding Standards, S. Smulikowska, A. Rutkowski (eds). 4th edn. The Kielanowski Institute of Animal Physiology and Nutrition, PAS, Jablonna (Poland) and Polish Branch of WPSA.

StatSoft, Inc. (2015). Statistica (data analysis software system), version 12.5.

S u B.C., Wang L.S., Wang H., Sh i B.M., Sh an A.S., L i Y.Z. (2013). Conjugated linoleic acid and betain prevent pork quality issues from diets containing distillers dried grains with solubles. Can. J. Anim. Sci., 93: 477-485.

Szarek J., Fabczak J., Zimnoch L., Koncicki A. (2000). Impact of feed additives on the morphological picture of internal organs of broiler chickens (in Polish). Zesz. Nauk. PTZ Prz. Hod., 49: 65-76.

Ś w i ą t k i e w i c z S., K o re le s k i J. (2003). An attempt to use dried corn distillers grains as a component of diets for broiler chickens (in Polish). Rocz. Nauk. Zoot., 30: 367-379.

Ś w i ą t k i e w i c z S., K o r e le s k i J. (2008). The use of distillers dried grains with solubles (DDGS) in poultry nutrition. World Poultry Sci. J., 64: 257-265.

Tomaszewska E., Muszyński S., Dobrowolski P., Kwiecień M., Klebaniuk R., 
Szy mańczyk S., Tomczyk A., Kowalik S., Milczarek A., Świetlicka I. (2018). The influence of dietary replacement of soybean meal with high-tannin faba beans on gut-bone axis and metabolic response in broiler chickens. Ann. Anim. Sci., 18: 801-824.

Wang Z., Cerrate S., Cot o C., Yan F., Wald roup P.W (2007). Utilization of distillers dried grains with solubles (DDGS) in broiler diets using a standardized nutrient matrix. Int. J. Poult. Sci., 6: $470-477$.

Wo y e ng o T.A., P at ter s on R., L e ve s que C.L. (2016). Nutritive value of extruded or multienzyme supplemented cold-pressed soybean cake for pigs. J. Anim. Sci., 94: 5230-5238.

WPSA (1989). European Tables of Energy Values for Poultry Feedstuffs. Spelderholt Centre Poult. Res., Beekbergen, The Netherlands.

Z a w i s to w s k i S. (1983). Histological technique: histology and basics of histopathology (in Polish). Wyd. 4. PZWL, Warszawa.

Zhaleh S., Golian A., Mirghelenj S.A., Akhavan A., Akbarian A. (2014). Effects of feeding various levels of full fat soybean extruded at high temperature on performance, serum components and intestinal morphology of broiler chickens. Anim. Prod. Sci., 55: 580-586.

Z i ołe c ki J., D o r u chow ski W. (1989). Slaughter value evaluation methods (in Polish). COBRD own publishing service, Poznań.

Received: 17 XII 2018

Accepted: 7 VIII 2019 